\title{
A remote sensing approach to understanding the archaeological potential: the case study of some Roman evidence in Umbria (Italy)
}

\author{
Pier Matteo Barone ${ }^{1, *}$, Luca Desibio ${ }^{2}$ \\ ${ }^{1}$ Archaeology and Classics Program, The American University of Rome, Via P. Roselli, 4 - 00153 Rome, Italy \\ ${ }^{2}$ Freelance Archaeologist, Rome, Italy
}

Email address:

p.barone@aur.edu (P.M. Barone), lucarcheo@gmail.com (L. Desibio)

\section{To cite this article:}

Pier Matteo Barone, Luca Desibio. A remote sensing approach to understanding the archaeological potential: the case study of some Roman evidence in Umbria (Italy). International Journal of Archaeology, Vol. 3, No. 1-1, 2015, pp. 37-44. doi: 10.11648/j.ija.s.2015030101.15

\begin{abstract}
In Umbria, the transformation from Roman pagan building to church seems to be frequent during the beginning of the Middle Age thanks to Longobards and Byzantines. The rural church of San Lorenzo in Nifili (close to Montecastrilli - TR) is a very good example of this. The aim of this work is to understand the evolution of the ancient landscape around this church, from Roman to modern period, using data coming from both the subsurface and the space, using the GPR (Ground Penetrating Radar) method and the satellite imageries, respectively. Particular data processing to define the evolution of this ancient landscape in southern Umbria is described in this paper. The results not only represent an effective and non-destructive methodology for discovering, recovering and understanding archaeological data, but also give the possibility to obtain archaeological potential values of different areas in order to better plan future researches in this area.
\end{abstract}

Keywords: Remote Sensing, NDT, GPR, Satellite Imagery Analysis, Roman Empire, San Lorenzo, Umbria

\section{Introduction}

In the Italian province of Terni (southern Umbria), the modern territories of Montecastrilli and Farnetta do not contain any important archaeological evidence, except for the rural church of San Lorenzo in Nifili and Santa Maria in Ciciliano. Here, the landscape appears different from the northern part of Umbria due to geological and settlement issues.

The Montecastrilli settlement is in a very good position between the ancient Via Flaminia (six kilometers west) and the Via Amerina (five kilometers east) and only four kilometers away from the ancient Via Ulpiana (called Via Petrosa in the Middle Ages). The little church of San Lorenzo in Nifili lies along a small secondary road between the territories of Montecastrilli and Farnetta (Fig. 1). It is generally accepted that this church is the result of the union between a Roman temple in antis and a circular funerary building [1] - [4].

Currently, the church appears to be built by bricks and squared stones with different dimensions according to, first, the Roman and then the Carolingian style [1]. From both the outside and the inside, it is possible to note the presence of some traces of frescos and interesting artifacts, which generally belong to a Roman temple. In particular, there is an interesting decoration on the external façade that is made of four fragments with an acanthus-volutes theme, which originally should have been part of a temple's frieze [5].

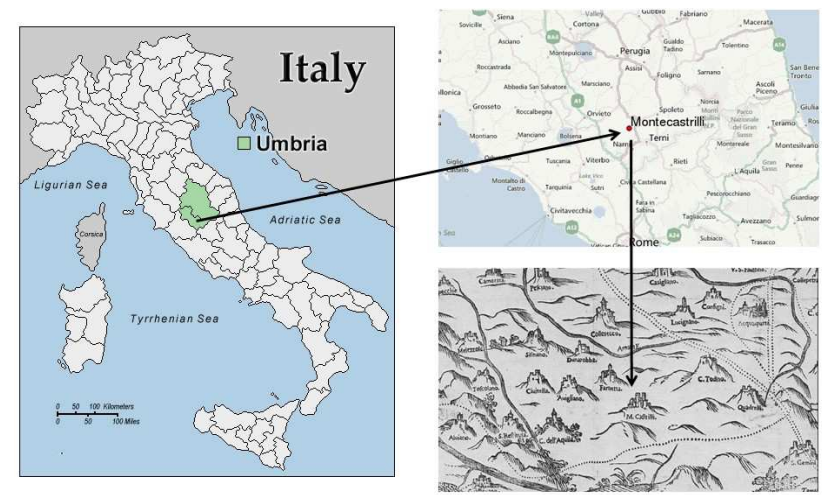

Figure 1. The localization of Montecastrilli in Italy with a detail of the ancient settlements in a historical cartography (bottom right) [2]-[4].

Today, it is possible to have an idea of this kind of frieze by observing the Roman Temple of Augustus in Pula (Croatia), 
which preserved an interesting and very similar frieze (Fig. 2) [6]. This represents a typical decoration of the Early-Imperial period, starting from an Augustan decoration [7]. In fact, the Augustan period corresponds not only to an important phase of reorganization in this area of Umbria but, in particular, to the first and more ancient construction phase of this building [8].
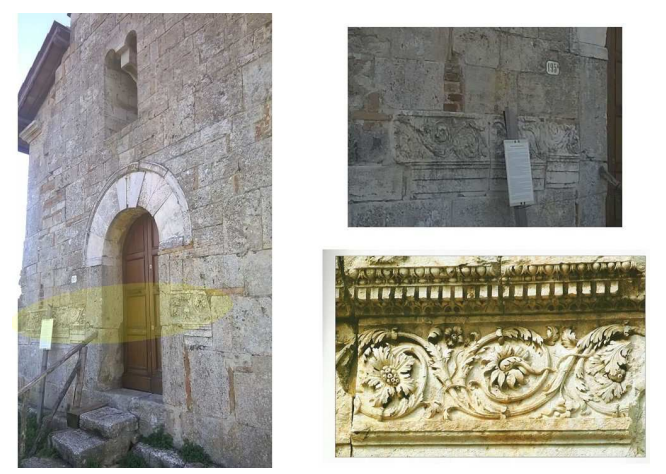

Figure 2. In the figure, it is possible to notice the precious frieze (highlighted in yellow) on the façade of the San Lorenzo in Nifili church. The top-right figure shows the magnification of the above-mentioned frieze, and the bottom-right figure illustrates the similar decoration on the Roman Temple of Augustus in Pula (Croatia).

It is worth noting that the territory of the modern church of San Lorenzo in Nifili belonged to the Municipium of Tuder during the Roman period. This is confirmed by the discovery of a Latin epigraph close to the church:

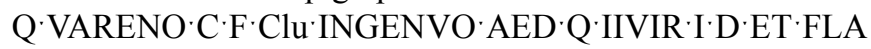
MINIAE'HOREIDI'cONCubINAE [9]. Reference [10] suggests that the quattroviro belongs to Tuder. Moreover, it seems that this area was donated to veterans during the Augustan period [8].

Another important evidence of the Early-Imperial period is the discovery of a so-called cippus carsulano. This cippus appears to be similar to urns from Chiusi (Tuscany, Italy) and represents a burial symbol (Fig. 3) [11]. This is also identified as an important boundary benchmark of the Carsulae's Roman territory. There is a widespread network of these cippi (almost 49 examples) delimiting a huge area ranging from Spoleto (the east side) to Montecastrilli (the west side), where San Lorenzo in Nifili represents the last settlement in the West [11]. The cippus dating is between the Social War $\left(1^{\text {st }}\right.$ century $\mathrm{BC})$ and the $1^{\text {st }}$ century AD [11].

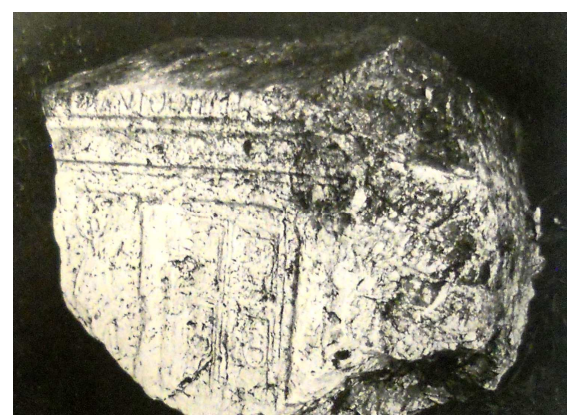

Figure 3. The figure shows the so-called cippus carsulano after its discovery [11].
The church of San Lorenzo in Nifili was erected on a small plateau reinforced by a small wall-structure on the western side where the apse is (Fig. 4). In this context, it seems possible to advance some hypothesis about the real function of this plateau and about the more ancient preexistences.

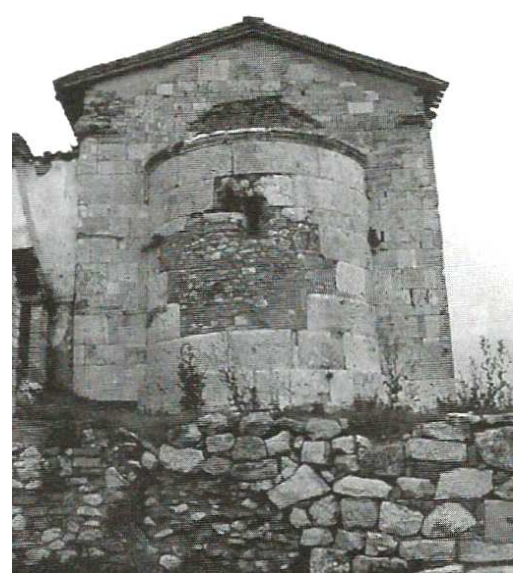

Figure 4. The apse of the church in 1985 [1]. Note the presence of an evident basement beneath the apse.

For these reasons, it was necessary to use a multi-technique approach in this region of interest. First, the possibility of remotely analyzing the area allows for a better definition of the archaeological assessments of all lands that are part of the investigation. Assessments are required, in this case, when the land has the potential to contain archaeological resources.

The main advantage of the remote sensing (RS) approach is the application of different non-destructive techniques (NDTs) to obtain the best result, in terms of both resolution and accuracy, without digging. Two of these NDTs, i.e., the satellite imagery analyses and the Ground Penetrating Radar (GPR) method, are used in this paper.

\section{Material and Methods}

\subsection{Satellite Imagery Analysis}

Satellites have been used over the past several decades to obtain a wide variety of information about the earth's surface, ranging from military applications to tracking global weather patterns, tectonic activity, surface vegetation, ocean currents and temperatures, polar ice fluctuations, pollution, and many other aspects. The application of satellite image analysis to archaeology has emerged alongside these other uses, but archaeologists are only now beginning to exploit more fully the broad range of analytical tools that are available for assessing the satellite image data of the earth's surface and sub-surface. The decreasing costs (e.g., as low as \$10), the increasing image resolutions (e.g., under one meter), and the greater availability (e.g., on-line purchasing) of satellite images for the general public is now making it possible for archaeologists to use satellite images more fully. The evolution of satellite image technology is also enabling the manipulation of a greater range of data contained in increasing types of satellite images (e.g., Aster, Corona, Landsat TM); 
archaeologists can now examine a broad spectrum of reflectivity signatures and bands within and between archaeological sites, including both surface and sub-surface features [12], and the literature thereof.

Satellite imagery analysis in archaeology enables researchers to understand the critical aspects of complex, nuanced archaeological issues more fully and more quickly than traditional desk top-based analysis. Researchers can also provide decision makers with the understanding that they need to ask the crucial questions sooner and non-destructively.

In this paper particularly, two different approaches were used: a multi-temporal and a background subtraction analysis. These imagery techniques are normally applied to computing or surveillance [13], and [14], but with some adaptions, it is possible to implement them both in this specific archaeological research.

\subsubsection{Multi-Temporal Images}

Over the last ten years, there was a significant increase in interest on topics related to time series and the analysis of multi-temporal data [15].

The increased interest in multi-temporal data analysis is due to many issues: an increased number of satellites with increased revisitation times that allow for the acquisition of either long time series or frequent bi-temporal images; new policies for distributing archive data that make retrospective analysis on a large scale possible (e.g., the Landsat Thematic Mapper archive); and new policies for distributing data from new satellites (e.g., ESA Sentinel) [16].

In this work, a Change Detection (CD) process is used to analyze multi-temporal remote sensing images that were acquired on the same geographical area to identify changes that occurred between the considered acquisition dates. In particular, the satellite images were collected in 1955, 2004, 2011, and 2014.

\subsubsection{Background Subtraction}

Background subtraction (BS) is one of the key techniques used for automatic analysis, particularly in the domain of satellite imagery [17]. The term BS covers a set of methods that aim to distinguish between foreground and background areas in satellite images utilizing a background model.

The main task of BS is to compare an input image against a background model. This model describes the background areas of the scene and is often represented by a distribution of features, such as color information. The so-called process of foreground detection determines which areas of an image belong to the foreground class with respect to the similarity of an input image and the background model. The result of this classification is a binary foreground mask [14].

In this work, the BS approach was necessary to better highlight the presence of anomalies in the very-shallow part of the soil (e.g., crop marks) and compare these with the on-site results of the GPR acquisitions.

\subsection{The GPR method}

GPR has recently become the most important physical technique in cultural heritage preservation, particularly for archaeology [18] - [29] and its literature.

Radar (RAdio Detection And Ranging) systems were initially developed as a means of using microwaves to detect the presence of objects, typically aircraft and ships, and derive their range from the transmitter. Radar is based on the transmission of radiation pulses and recording of the reflections. Advances in radar technology have observed the development of systems that are capable of providing ground surface images from aircraft or space and systems that can penetrate the ground, enabling subsurface features to be mapped. This latter system is known as GPR, and it differs from the systems used to detect aircraft and ships by providing images of the ground surface and in terms of the power and wavelength of the transmitter signal. GPR operates at frequencies between a few $\mathrm{MHz}$ and $3 \mathrm{GHz}$, and the depth of the penetration is sensitive to the electrical properties of the ground [30], [31].

In this work, the data were collected using a bistatic GPR (Findar, Sensors \& Software, Inc.) equipped with $500 \mathrm{MHz}$ antennas and a commercial GPS. The step-size was $2.5 \mathrm{~cm}$, the stacking was 4 , and the signal-penetration velocity was $0.12 \mathrm{~m} / \mathrm{ns}$ due to the hyperbola calibration. A total of 2.5 ha were covered in three different areas: Area 1 (south of the church); Area 2 (around the church); and Area 3 (north of the church).

The GPR system was able to collect data of good quality that did not require specific filtering or signal recovery processing. To identify the buried targets, each radar section was analyzed by applying the basic Dewow time filter and the Automatic Gain Control (AGC).

\section{Results}

\subsection{Area 1}

Starting with the multi-temporal analysis, in 1955, the presence of an ancient road cutting through the investigated area and passing in front of the entrance of the church is evident (Fig. 5b). This road is no longer visible in either the recent satellite images or on-site. The possibility to apply the BS allows us to highlight not only the evidence of this ancient road but also the presence of three other linear anomalies (Fig. $5 \mathrm{c})$.

Based on this evidence, it was necessary to use the GPR technique to better understand the subsurface situation. The collected data show the presence of clear and strong reflectors. In Fig. 5d, at a depth of approximately $1 \mathrm{~m}$, several red, elongated, and partially right-angle anomalies confirm not only the road beneath the surface but also some partially preserved wall structures that exist due to the recent damage caused by an artificial slope for mining purposes.

These relevant structures could be related to some Roman brick buildings, most likely in association with the religious function of the area in that period. Moreover, during the recent work for mining purposes, some brick remains along the slope were brought to light (Fig. 5e). 
40 Pier Matteo Barone and Luca Desibio: A remote sensing approach to understanding the archaeological potential: the case study of some Roman evidence in Umbria (Italy)

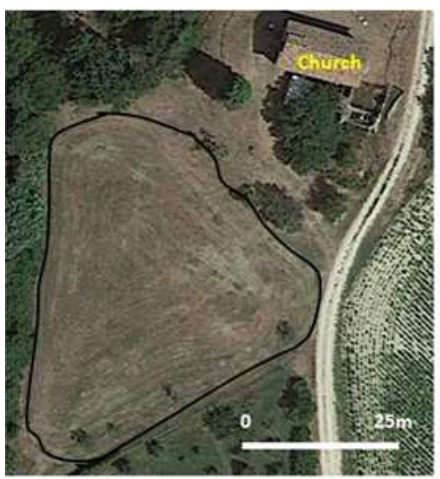

A

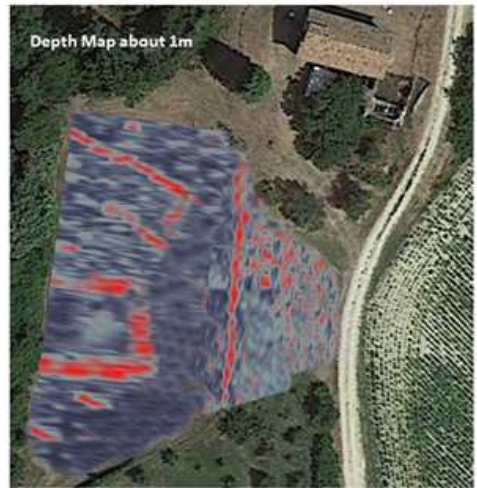

D

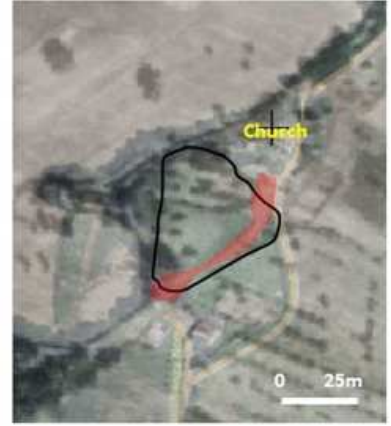

B

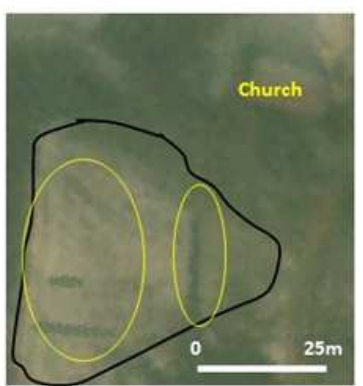

C

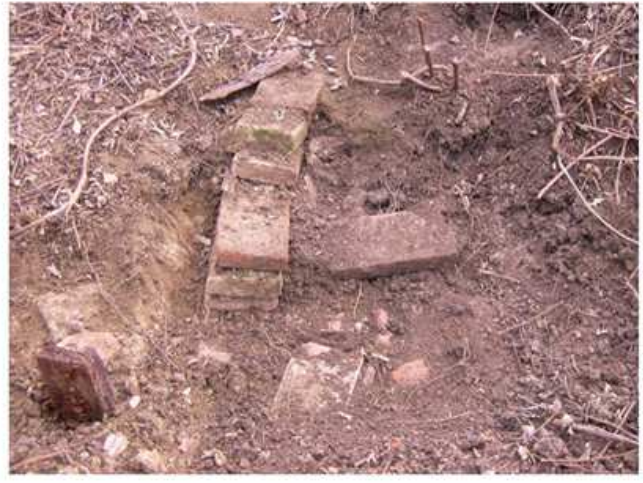

Figure 5. Figure 5a shows the investigated area south of the church; fig. $5 \mathrm{~b}$ is the overlap of the 1955 and 2004 satellite image in which the ancient (in red) and modern (in yellow) road is clear to see; fig. $5 c$ is the result of the BS, and it is clearly observed in the subsurface the presence not only of the anomaly due to the ancient road (on the right) but also other anomalies (on the left); fig. $5 d$ depicts the GPR penetration map at a depth of $1 \mathrm{~m}$ circa in which elongated and right-angle reflectors (in red) are evident due to the ancient road and to wall structures; finally, fig. 5e illustrates the presence of brick remains in the slope close to the investigated area after a recent excavation for mining purposes.

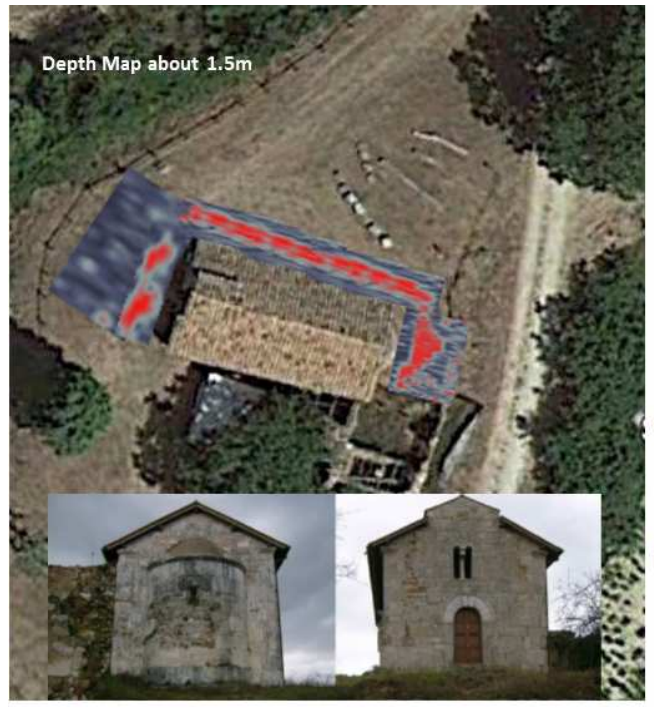

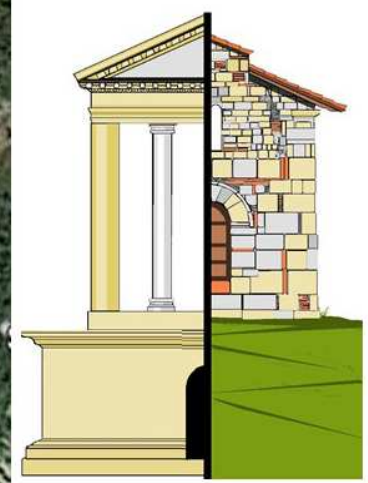

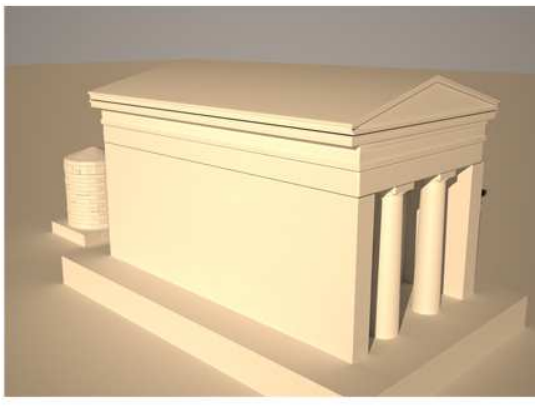

C

Figure 6. Figure 6a shows the GPR penetration map at a depth of approximately $1.5 \mathrm{~m}$. It is worth noting the presence of a semi-circular anomaly in correspondence to the apse of the church. Fig. $4 b$ and $4 c$ reconstruct not only the Roman temple in antis and its basement but also the whole religious complex made by the temple and the circular funerary building. 


\subsection{Area 2}

Unfortunately, the multi-temporal and the BS analysis for Area 2 was not as helpful as that for Area 1. For this reason, only the GPR investigation was performed. Nevertheless, the GPR results indicate a very interesting implication. Fig. 6a illustrates the presence of several anomalies, some surrounding the church and some larger than it, at a depth of approximately $1.5 \mathrm{~m}$. Moreover, corresponding to the apse of the church, the anomaly presents a semi-circular shape.

These results seem to be in agreement to what [1] reports about the presence of a Roman temple in antis and a Roman circular funerary building. Fig. $6 \mathrm{~b}$ depicts a reconstruction of the temple in comparison with how the church looks today. It is worth noting the presence of a consistent basement in agreement with the GPR anomalies detected along and in front of the church. Fig. 6c recreates the religious complex by putting together the temple in antis and the circular funerary building, which was partially reused afterwards, as the apse of the more recent church.

These reconstructions are supported by an architectural analysis of the modern structures. It seems to be clear that the temple in antis has preserved this 'hidden' form in the recent church, transforming, for example, the ancient façade with the two columns in the main façade of the church.

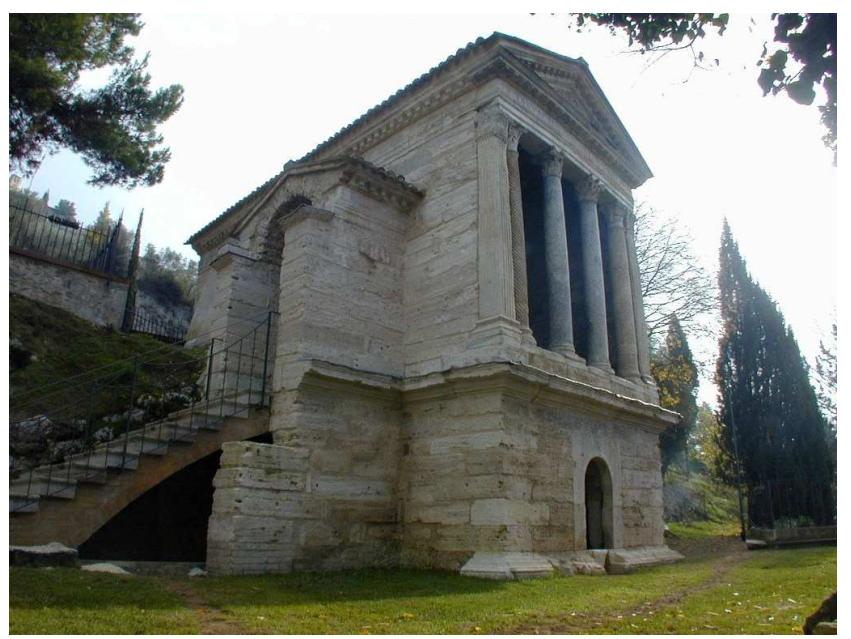

Figure 7. The Temple of Clitunno (Campello sul Clitunno, PG, Italy).

This is also confirmed by comparing this church with the Roman Temple of Clitunno (Campello sul Clitunno, PG, Italy) (Fig. 7). The aspect of this temple should be very similar to the ancient temple before the church of San Lorenzo in Nifili. Moreover, it was converted during the century from a pagan temple to a Christian church exactly in the same way as what likely occurred to the church of San Lorenzo in Nifili [32].

Observing the external basement of the apse in the 1985 picture (Fig. 4), it is possible to note not only that this basement is no longer visible today (Fig. 6a), but also that the massive thickness of the apse is greater beneath the soil. Indeed, considering the Temple of Clitunno, it is possible to have an idea of what could be buried under the plateau below San Lorenzo in Nifili. Consequently, if the lower and more ancient part of both the basement of the Roman temple in antis (in particular the massive basement) and the circular funerary building is buried beneath, the restoration (i.e., the reuse) of the ancient structures as a church has modified only the upper part of the temple, absorbing both the ancient basement as the 'foundation-plateau' for the new church and the circular funerary structure as a partial base for the apse.

\subsection{Area 3}

Area 3 is the top of a large decline that lies north of the church. Here, during a field-walking survey, several scattered remains of archaeological material were found over the last five years. These remains (e.g., glasses, pottery such as terra sigillata or dolia, pieces of marbles, parts of mortars, tiles of mosaics) were dated to a period including the $1^{\text {st }}$ and $2^{\text {nd }}$ centuries AD (Fig. 8) [5].
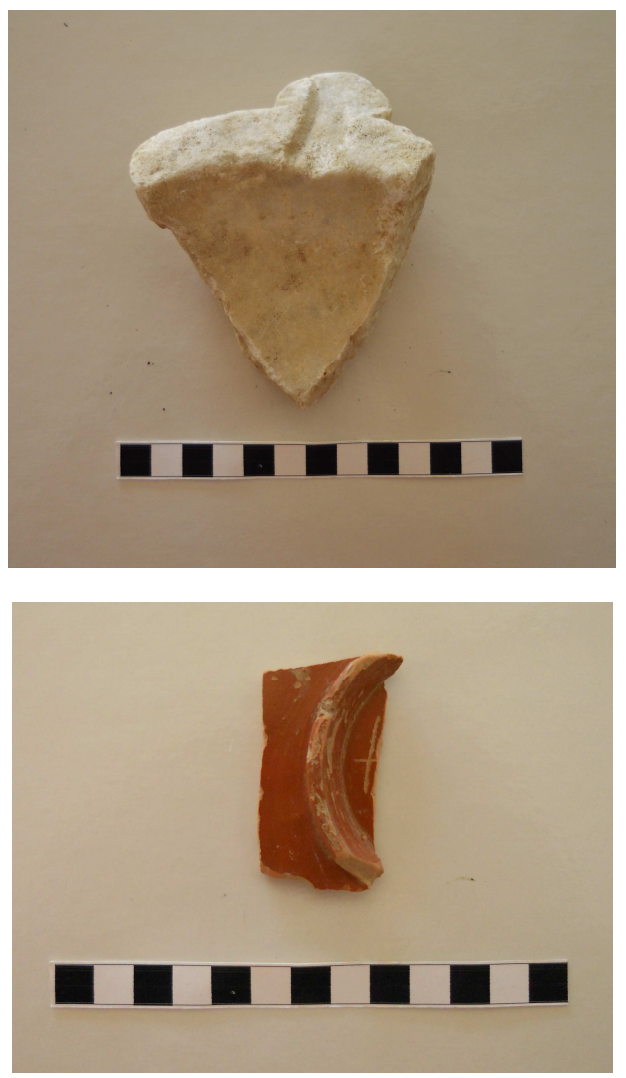

Figure 8. In the figure, it is possible to recognize some remains found in Area 3: a piece of ' $H$ ' engraved terra sigillata (on the left), and a part of a mortar (on the right).

This amount of materials on the surface of the area suggests the presence of a Roman mansio (i.e., an official stopping place on a Roman road, maintained by the central government for travelers).

The multi-temporal study of the area, together with the BS analysis, provides interesting results about the very shallow subsurface. Fig. 9 shows relevant anomalies particularly in the zone in which the GPR have collected the data.

In fact, Fig. 10 corroborates this, illustrating elongated GPR reflectors at a depth of approximately $1 \mathrm{~m}$, which are most 
likely linked to ancient manmade structures. Note that the presence of the decline close to this area and the intense use of mechanized agriculture over the centuries could have partially destroyed other structural remains, scattering on the surface only the small pieces found later during the field-walking survey. Moreover, it also possible that other remains can be found in the subsurface of the decline (not yet investigated) due to the natural collapse of a slope.

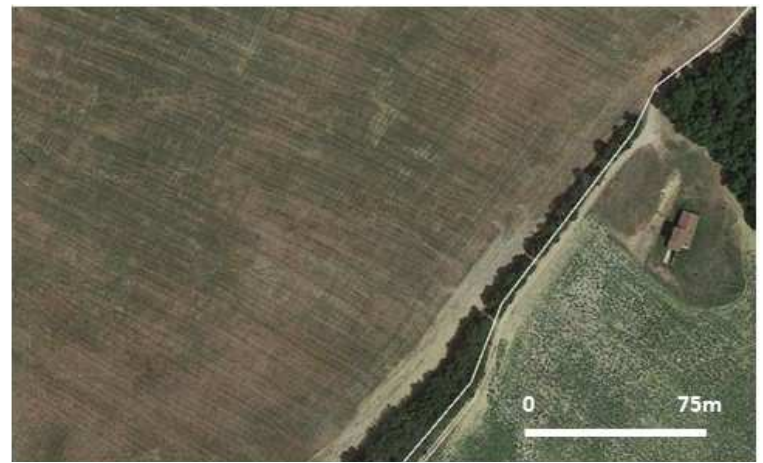

\section{Conclusion}

Based on these results, it is possible to create a sort of table of the archaeological potential of this region to plan future studies. Tab. 1 lists the three areas investigated and the corresponding Bayesian values of archaeological potential according to [33].

Figure 9. Figure 9 shows, on the left, Area 3 in the 2004 satellite image. On the right, the BS results are highlighted, illustrating in the subsurface the presence of some not well-defined anomalies.

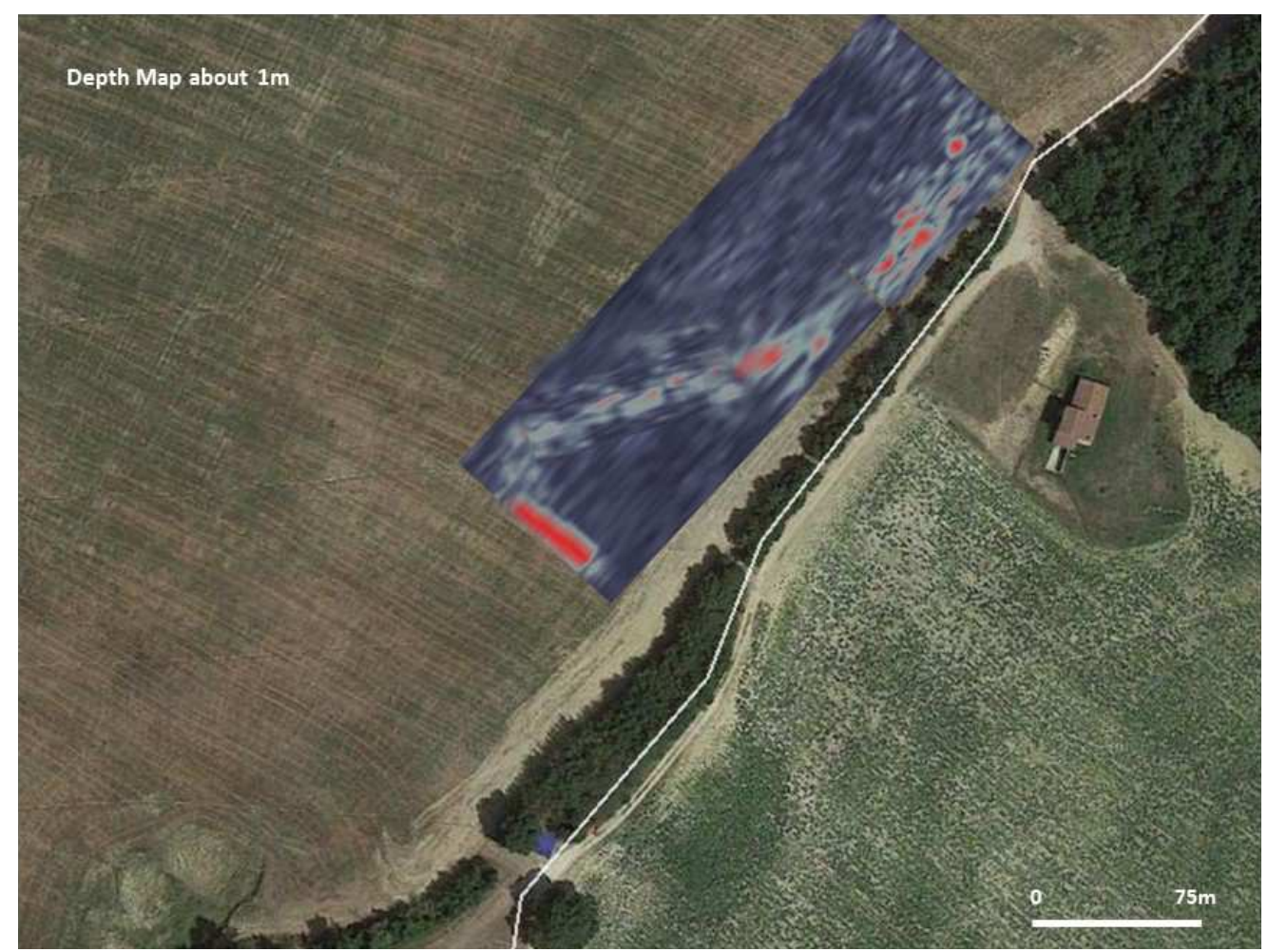

Figure 10. In this figure, it is possible to notice the elongated strong GPR anomalies in Area 3 at a depth of approximately $1.5 \mathrm{~m}$. Due to their geometry, it is possible they are linked to ancient manmade structures.

Table 1. The archaeological potential of the three investigated areas

\begin{tabular}{ll}
\hline Name & Value \\
\hline Area 1 & High \\
Area 2 & High \\
Area 3 & Medium to High \\
\hline
\end{tabular}

The integrated approach of remote sensing, satellite imagery, and GPR, when applied to better understanding the evolution of an ancient landscape, not only represents an effective and non-destructive methodology for discovering, recovering, and understanding archeological data but also gives the possibility to obtain archaeological potential values of different areas and thereby better plan future studies.

In particular, this paper demonstrates the effectiveness of a combined method to highlight the importance of a region of interest, pursue archaeological research, and produce precise 
assessments in terms of caring for cultural heritage sites.

\section{Acknowledgements}

We are grateful to Dr. Maria Teresa Levanto for the 3D reconstruction of the temple in Figure 5c.

\section{References}

[1] S. Carpinelli, and S. Chianella, "La chiesa di San Lorenzo in Nifili nella Parrocchia di Farnetta", in M. Corradi, M. (ed) Castrum Farnectae,le famiglie la storia le cronache di un castello umbro. Del Gallo, Spoleto, 2005.

[2] R. Almagià, "Monumenta Cartographica Vaticana, II, Carte geografiche a stampa di particolare pregio o rarità dei secoli XVI e XVII esistenti nella Biblioteca Apostolica Vaticana", Città del Vaticano, Biblioteca Apostolica Vaticana, 1948.

[3] F. Ronca, and A. Volpini, "Alla ricerca dei confini. L'Umbria nella cartografia storica dal XVI all'unità d'Italia", Terni, Arti grafiche, 2011.

[4] R. Volpi, "Le regioni introvabili. Centralizzazione e regionalizzazione dello Stato Pontificio", Bologna, il Mulino, 1983.

[5] L. Desibio, "Territory and Borders in Southern Umbria and the Christianization of pagan sanctuaries" in Proceedings of the Frontiers of the European Iron Age Conference, Cambridge, 2013, pp. 11-12.

[6] G. Pavan, "Il tempio d'Augusto di Pola, Istituto Giuliano di Storia, Cultura e Documentazione", Collana di Architettura 2, Trieste-Gorizia, 2000.

[7] P. Zanker, "The Power of images in the Age of August", University of Michigan Press, 1990.

[8] L. Bonomi Ponzi, and C. Giontella, "L' Umbria meridionale dalla protostoria all'alto Medioevo", Interamna. Quaderni di Storia dell'Arte, Terni, 1995.

[9] Corpus Inscriptionum Latinarum, XI, 4662.

[10] S. Sisani, "Fenomenologia della conquista: la romanizzazione dell'Umbria tra il IV sec. a.C. e la Guerra Sociale", Roma, Quasar, 2007.

[11] S. Diebner, "Cippi Carsulani”, Archeologia Classica, 38, pp. 35-66.

[12] S.H. Parcak, "Satellite Remote Sensing for archaeology", Routledge, 2009.

[13] C. S. Arvind, Ashoka Vanjare, S. N. Omkar, J. Senthilnath, V. Mani, P. G. Diwakar, "Multi-temporal Satellite Image Analysis Using Unsupervised Techniques", in Advances in Computing and Information Technology, Advances in Intelligent Systems and Computing, Volume 177, 2013, pp. 757-765. DOI: 10.1007/978-3-642-31552-7_77

[14] S. Brutzer, B. Höferlin, and G. Heidemann, "Evaluation of Background Subtraction Techniques for Video Surveillance", Computer Vision and Pattern Recognition (CVPR), IEEE, 2011, pp. 1937-1944. DOI: 10.1109/CVPR.2011.5995508

[15] K. Saheb, R. Farah, Bassel S., and Ben-Ahmed M., "Toward a
Multi-Temporal Approach for Satellite Image Interpretation", The International Arab Journal of Information and Technology, 5, 3, 2008, pp. 281-287.

[16] L. Bruzzone, "Current scenario and challenges in the analysis of multitemporal remote sensing images", GRSS-IEEE, 2010.

[17] S. Herrero, and J. Bescòs, "Background subtraction techniques: Systematic evaluation and comparative analysis", in Advanced Concepts for Intelligent Vision Systems, Springer, 2009, pp. 33-42. DOI: 10.1007/978-3-642-04697-1_4

[18] L. Orlando, and E. Slob, "Using multicomponent GPR to monitor cracks in a historical building", Journal of Applied Geophysics, 67, 2009, pp. 327-334. DOI: 10.1016/j.jappgeo.2008.09.003

[19] V. Perez-Gracia, J.O. Caselles, J. Clapes, G. Martinez, and R. Osorio, "Non-destructive analysis in cultural heritage buildings: Evaluating the Mallorca cathedral supporting structures". NDT \& E International, 59, 2013, pp. 40-47. DOI: 10.1016/j.ndteint.2013.04.014

[20] E. Pettinelli, P.M. Barone, A. Di Matteo, E. Mattei, and S.E. Lauro, "Radio waves technique for non-destructive archaeological investigations", Contemporary Physics, 52, 2, 2011, pp. 121 - 130. DOI: 10.1080/00107514.2010.545208

[21] E. Pettinelli, P.M. Barone, E. Mattei, A. Di Matteo, and F. Soldovieri, "Archaeology and Cultural Heritage", in A.S. Turk, A.K. Hocaoglu, and A.A. Vertiy (eds.), Subsurface Sensing, Wiley, 2011, pp. 644-667.

[22] E. Pettinelli, P.M. Barone, A. Di Matteo, E. Mattei, and S.E. Lauro, Mapping the undiscovered ruins of Pompeii (Naples, Italy) using Ground-penetrating Radar, Archaeometry, 54, 1, 2012, pp. 203-212. DOI: 10.1111/j.1475-4754.2011.00599.x

[23] P.M. Barone, A. Di Matteo, F. Graziano, E. Mattei, and E. Pettinelli, "GPR application to historical buildings structural control", Near Surface Geophysics, 8, 5, 2010, pp. 407-413: DOI: $10.3997 / 1873-0604.2010017$

[24] P.M. Barone, S.E. Lauro, E. Mattei, and E. Pettinelli, "Non-destructive technique to investigate an archaeological structure: a GPR survey in the Domus Aurea (Rome, Italy)", in Proceedings of the 13th International Conference on Ground Penetrating Radar, Lecce, GPR 2010, IEEE, 2010. DOI: 10.1109/ICGPR.2010.5550087

[25] P.M. Barone, T. Bellomo, E. Mattei, S.E. Lauro, and E. Pettinelli, "Ground-penetrating Radar in the Regio III (Pompeii, Italy): Archaeological Evidence", Archaeological Prospection, 18, 3, 2011, pp. 187-194. DOI: 10.1002/arp.405

[26] P.M. Barone, C. Ferrara, and E. Pettinelli, "How could Archeo-Geophysics help garbage disposal? A fortuitous discovery in Central Italy", Antiqua, 2, 1, 2012, pp. e3. DOI: 10.4081/antiqua.2012.e3

[27] P.M. Barone, C. Ferrara, and E. Pettinelli, "Advanced ground penetrating radar applied to landscape archaeology and cultural heritage", in Vermeulen F. and Corsi C. (eds.), Non-destructive approaches to complex archaeological sites in Europe: a round-up, Ghent University, 2013. ISBN 978-94-6197-109-8

[28] P.M. Barone, E. Mattei, and E. Pettinelli, "Non-invasive archaeological exploration in stratigraphically complex rural settings: an example from Ferento (Viterbo, Italy)", Archaeological and Anthropological Sciences, 5, 3, 2013, pp. 267-273. DOI: $10.1007 / \mathrm{s} 12520-013-0138-3$ 
44 Pier Matteo Barone and Luca Desibio: A remote sensing approach to understanding the archaeological potential: the case study of some Roman evidence in Umbria (Italy)

[29] P.M. Barone, and E. Pettinelli, Non-destructive techniques in archaeology: recent GPR investigations in Crustumerium, in Attema P.A.J., Di Gennaro F. and Jarva E. (eds.), Crustumerium. Ricerche internazionali in un centro latino. Archaeology and identity of a Latin settlement near Rome, vol. 1, 2013, pp. 45-53.

[30] A.P. Annan, "Ground Penetrating Radar: principles, procedures \& applications", Sensors \& Software, Inc, 2004, Technical paper.

[31] H. Jol, "Ground Penetrating Radar Theory and Applications", Elsevier, 2009.
[32] D. Scortecci, "Trasformazione degli edifici pagani in edifici di culto cristiano", in Umbria cristiana. Dalla diffusione del culto al culto dei santi (secc. IV-X), Atti del $15^{\circ}$ Congresso internazionale di studi sull'Alto Medioevo, Spoleto 23-28 ottobre 2000, Spoleto, Centro italiano di studi sull'Alto Medioevo, 2001, pp. 367-92.

[33] C. Orton, "A Bayesian approach to a problem of archaeological site evaluation", in K. Lockyear, T.J.T. Sly, and V. Mihailescu-Birliba (eds.), CAA96, Computer Applications and Quantitative Methods in Archaeology, BAR International Series 845, archaeopress, Oxford, 2000. 